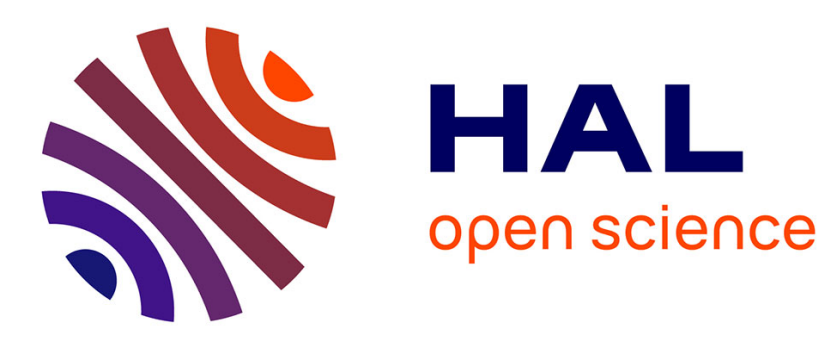

\title{
Cosmopolitanized Nations: Reimagining Collectivity in World Risk Society
}

\author{
Ulrich Beck, Daniel Levy
}

\section{To cite this version:}

Ulrich Beck, Daniel Levy. Cosmopolitanized Nations: Reimagining Collectivity in World Risk Society. 2012. halshs-00795250

\section{HAL Id: halshs-00795250 \\ https://shs.hal.science/halshs-00795250}

Preprint submitted on 27 Feb 2013

HAL is a multi-disciplinary open access archive for the deposit and dissemination of scientific research documents, whether they are published or not. The documents may come from teaching and research institutions in France or abroad, or from public or private research centers.
L'archive ouverte pluridisciplinaire HAL, est destinée au dépôt et à la diffusion de documents scientifiques de niveau recherche, publiés ou non, émanant des établissements d'enseignement et de recherche français ou étrangers, des laboratoires publics ou privés. 


\title{
Collège d'études mondiales
}

\section{Cosmopolitanized Nations: Reimagining Collectivity in World Risk Society}

\author{
Ulrich Beck \& Daniel Levy
}

$\mathrm{N}^{\circ} 26$ | february 2013

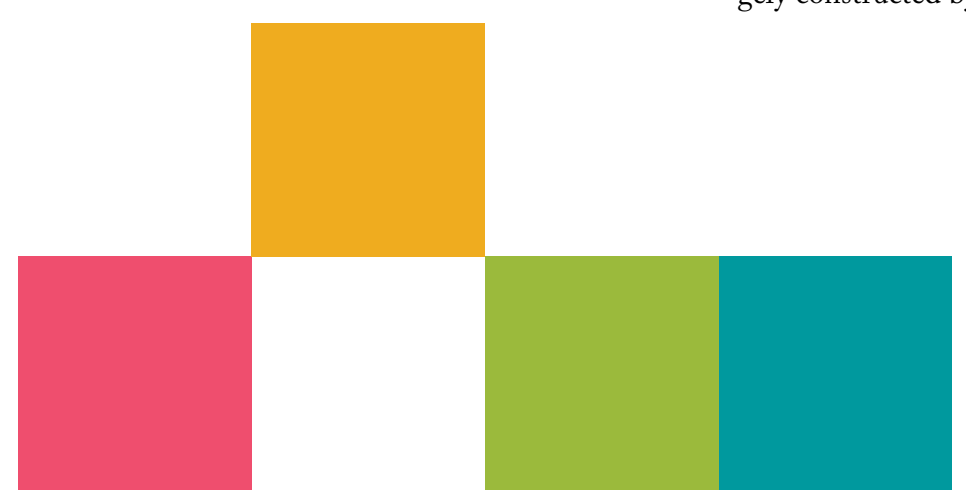

Cosmopolitan sociology has tackled broad themes like risk, family, religion, power, war, inequality, memory, and civil society movements exploring their reconfiguration in the global age. Tellingly, the concept of the national is often perceived, both in public and scientific discourse as the central obstacle for the realization of cosmopolitan orientations. Consequently, debates about the nation tend to revolve around its persistence or its demise. We depart from this either-or perspective by investigating the formation of the 'cosmopolitanized nations' as a facet of world risk society. This re-imagination of nationhood evolves, among other things, in the context of global norms (e.g. human rights), globalized markets, transnational migrations and embeddedness in international organizations. Here we focus on a mechanism involving the promulgation of 'risk societies'. Modern collectivities are increasingly pre-occupied with debating, preventing and managing risks. However, unlike earlier manifestations of risk characterized by daring actions or predictability models, global risks cannot be calculated or forecast anymore. Accordingly, more influence accrues to the perception of risk, largely constructed by media representations of disasters.

Working Papers Series 


\section{Cosmopolitanized Nations: Reimagining Collectivity in World Risk Society}

\section{Ulrich Beck \& Daniel Levy}

February 2013

\section{The authors}

Ulrich Beck, since 1992, has been professor for sociology and director of the Institute for Sociology of Munich University. He is also the British Journal of Sociology Professor at the London School of Economics and holds the Chaire Re-mapping inequality and power in an age of climate change: the emergence of «cosmopolitan» risk communities at the Collège d'études mondiales. Beck currently studies modernization, ecological problems, individualization and globalization. Recently he has also embarked on exploring the changing conditions of work in a world of increasing global capitalism, declining influence of unions and flexibilisation of the labour process, a new theory rooted in the concept of cosmopolitanism. Among his recent works : Power in the Global Age (Cambridge: Polity Press, 2005); Cosmopolitan Vision (Cambridge: Polity Press, 2006); \& Edgar, G., Cosmopolitan Europe (Cambridge: Polity Press, 2007); World at Risk (Cambridge: Polity Press, 2009).

Daniel Levy is an Associate Professor of Sociology at the State University of New York at Stony Brook. $\mathrm{He}$ is a specialist on issues relating to globalization, collective memory studies, and comparative historical sociology. Among his recent books: Human Rights and Memory (Pennsylvania State University Press, 2010) with Natan Sznaider; The Collective Memory Reader (Oxford University Press, 2011) with Jeffrey K. Olick and Vered Vinitzky-Seroussi.

\section{Citing this document}

Ulrich Beck \& Daniel Levy, Cosmopolitanized Nations: Reimagining Collectivity in World Risk Society, FMSH-WP-2013-27, february 2012.

(c) Fondation Maison des sciences de l'homme - 2012

Informations et soumission des textes : wpfmsh@msh-paris.fr

Fondation Maison des sciences de l'homme 190-196 avenue de France 75013 Paris - France

http://www.msh-paris.fr http://halshs.archives-ouvertes.fr/FMSH-WP http://wpfmsh.hypotheses.org
Les Working Papers et les Position Papers de la Fondation Maison des sciences de l'homme ont pour objectif la diffusion ouverte des travaux en train de se faire dans le cadre des diverses activités scientifiques de la Fondation : Le Collège d'études mondiales, Bourses Fernand Braudel-IFER, Programmes scientifiques, hébergement à la Maison Suger, Séminaires et Centres associés, Directeurs d'études associés...

Les opinions exprimées dans cet article n'engagent que leur auteur et ne reflètent pas nécessairement les positions institutionnelles de la Fondation MSH.
The Working Papers and Position Papers of the FMSH are produced in the course of the scientific activities of the FMSH: the chairs of the Institute for Global Studies, Fernand Braudel-IFER grants, the Foundation's scientific programmes, or the scholars hosted at the Maison Suger or as associate research directors. Working Papers may also be produced in partnership with affiliated institutions.

The views expressed in this paper are the author's own and do not necessarily reflect institutional positions from the Foundation MSH. 


\section{Abstract}

Cosmopolitan sociology has tackled broad themes like risk, family, religion, power, war, inequality, memory, and civil society movements exploring their reconfiguration in the global age. Tellingly, the concept of the national is often perceived, both in public and scientific discourse as the central obstacle for the realization of cosmopolitan orientations. Consequently, debates about the nation tend to revolve around its persistence or its demise. We depart from this either-or perspective by investigating the formation of the 'cosmopolitanized nations' as a facet of world risk society. This re-imagination of nationhood evolves, among other things, in the context of global norms (e.g. human rights), globalized markets, transnational migrations and embeddedness in international organizations. Here we focus on a mechanism involving the promulgation of 'risk societies'. Modern collectivities are increasingly preoccupied with debating, preventing and managing risks. However, unlike earlier manifestations of risk characterized by daring actions or predictability models, global risks cannot be calculated or forecast anymore. Accordingly, more influence accrues to the perception of risk, largely constructed by media representations of disasters.

In a first step we distinguish between a normative cosmopolitanism and analytic cosmopolitization processes. The cosmopolitanized nations, we argue, reflect a new mode of collective identification, whereby we differentiate between presumptions of thick belonging and the actual proliferation of cosmopolitan affiliations. This leads to a gradual distinction between a conventional (and naturalized) view of the national and an emerging figuration of cosmopolitan nationhood. In a second step we overcome the territorial fixation of the social sciences by shifting our attention to temporal dimensions, with a particular focus on competing conceptions of the future. Our findings suggest that cosmopolitanized nations are reimagined through the anticipation of endangered futures. In a third step we demonstrate how these cosmopolitan transformations of nationhood are taking place in the context of the emergence of a world risk society regime that marshalls a set of cosmopolitan imperatives situating the global other in our midst. In a fourth step we illustrate these developments by exploring how the mediatization of risk, and concomitant notions of the future contribute to the re-imagination of cosmopolitan risk collectivities.

\section{Keywords}

Cosmopolitanism, future, risk society, nationhood, cosmopolitanization, social sciences

\section{Les « nations cosmopolitanisées 》: la réinvention de la collectivité dans une société du risque}

\section{Résumé}

La sociologie du cosmopolitisme a abordé de nombreuses thématiques, telles que le risque, la religion, la famille, le pouvoir, l'inégalité, la mémoire et les mouvements citoyens, explorant leur reconfiguration dans un monde global. De manière révélatrice, le concept de nation/national est souvent perçu, dans le discours public comme dans le discours scientifique, comme l'obstacle majeur à la mise en œuvre d'orientations cosmopolites. Par conséquent, les débats portant sur la nation questionnent invariablement sa survivance ou sa disparition. Nous nous écartons de cette approche binaire en étudiant la formation de « nations cosmopolitanisées » en tant qu'une des facettes de la société mondiale du risque. Cette réinvention de la notion de nation évolue, entre autres choses, dans le contexte des normes globales (par exemple les droits humains), des marchés mondialisés, des migrations transnationales et de l'imbrication au sein d'organisations internationales. Ici, nous nous intéressons à un processus qui prend en considération la propagation de "sociétés du risque ». Les collectivités modernes se soucient de plus en plus de débattre autour de la notion de risque, de le prévenir et de le gérer. Néanmoins, et contrairement à des manifestations antérieures de risques résultant d'actions hasardeuses ou relevant de schémas prévisibles, les risques globaux ne peuvent plus être désormais ni calculés ni prévus. De ce fait, c'est la perception du risque qui accroit son influence, celle-ci étant largement construite par la couverture médiatique des catastrophes. 
Dans un premier temps, nous établissons une distinction entre des processus de cosmopolitisme normatif et de cosmopolitisation analytique. Less nations cosmopolitanisées, selon nous, renvoient à un nouveau mode d'identification collective, dans lequel nous faisons la différence entre des présomptions d'appartenance forte et la prolifération avérée d'affiliations cosmopolites. Cela mène à une distinction progressive entre une approche conventionnelle (et naturalisée) du fait national et une représentation émergente de la nationalité cosmopolite. Dans un deuxième temps, nous dépassons l'ancrage territorial des sciences sociales en déplaçant la focale sur leur dimension temporelle, et plus particulièrement sur les représentations concurrentes du futur. Nos conclusions suggèrent que les nations cosmopolitanisées sont réimaginées par l'anticipation de futurs dangereusement incertains. Dans un troisième temps, nous démontrons comment ces transformations cosmopolitaines de la nation prennent place dans un contexte où émerge un régime de la société du risque qui mobilise une série d'impératifs de nature cosmopolite qui situe l'autre global en notre sein. Dans un quatrième temps, nous illustrons ces conclusions en explorant la façon dont la médiatisation du risque, et les représentations du futur qui en résultent, contribuent à la réinvention des collectivités cosmopolites du risque.

\section{Mots-clés}

cosmopolitisme, sociologie, société du risque, futur, sciences sociales, fait national

\section{Sommaire}

The Nationalism-Cosmopolitanism Divide

From National Time

to Cosmopolitan Times

Cosmopolitan Figurations

\section{Creating the Cosmopolitanized Nations:}

The World Risk Society Regime of Transformation

The human rights imperative

The world market imperative

Migration as the prism for Otherhood

('The global Other is in our midst')

Global generations and civil society movements

Interpenetration of world religions

Shifting global power or the decentralization of the centre

Cosmopolitan realism

\section{Media(tion) and the ReimagiNation of Cosmopolitan Risk Collectivities}


The NationalismCosmopolitanism Divide $\mathrm{M}$ uch of the social science literature on the nation-state is caught in a resilient methodological nationalism bound up with the presupposition that the national-territorial remains the primary container for the analysis of social, economic, political and cultural processes. At the beginning of the twenty-first century, globalization is posing a political and theoretical challenge to the idea that binding history and borders tightly together is the only possible means of social and symbolic integration. There is by now an established body of cosmopolitan literature making significant advances to overcome the prevailing methodological nationalism in the social sciences. ${ }^{1}$ This burgeoning field underscores the need to develop an analytical idiom of 'modern society' not limited to a national ontology and suggestive of alternative modes of belonging.

Notwithstanding, cosmopolitanism too often remains addressed within a set of polarities. For one, it is frequently treated as a normative concept focusing on a static ism rather than a process oriented notion of cosmopolitization. This normative outlook tends to imply an antidote to nationalism (Nussbaum 1996). On this view, the discussion revolves around a dichotomy of the national and the cosmopolitan, which is mirrored in a juxtaposition of universalism (often decried as a form of Western imposition) and particularism (often dismissed as cultural relativism). Lastly, these polarities are underwritten by a simplistic (and a-historical) dichotomy of thick national versus thin cosmopolitan belonging. At

1. Among the conceptual contributions are: Adam 2004; Appiah 2006; Archibugi 2008; Beck 2002, 2005, 2006, 2009; Beck and Grande 2007, 2010a; Beck and Sznaider 2006a, 2006b, 2006c, 2010; Benhabib 2007; Boon and Fine 2007; Breckenridge et al. 2002; Brown 2008; Calcutt, Woodward and Skrbis 2009; Calhoun 2006, 2007; Cheah 2006; Delanty 2009; Dobson 2006; Featherstone et al. 2002; Fine 2007; Fine and Chernilo 2004; Held 2010; Kendall, Woodward and Skrbis 2009; Khagram and Levitt 2008; Kurasawa 2004; Lamont and Aksartova 2002; Levy and Sznaider 2006a, 2010; Mau, Mewes and Zimmermann 2008; Nederveen Pieterse 2006; Nowicka and Rovisco 2009; Pichler 2008; Rapport 2007; Roudometof and Haller (2007); Rumford 2007; Saito 2011; Vertovec and Cohen 2002; Werbner 2008; Wimmer and Glick Schiller 2002; Special volumes dedicated to cosmopolitanism were published in the British Journal of Sociology 2006, Constellations 2003, Daedalus 2008, the European Journal of Social Theory 2007, Theory, Culture and Society 2004 and The Hedgehog Review 2009. the core of these dualities is an assumption that belonging operates primarily, even exclusively, in the context of communal allegiances expressing thick solidarities.

Regardless of their understanding that the nation is a constructed category, most cosmopolitan scholars 'accept that it is or was the natural and rational form of socio-political organization in the modern age, i.e. that it is or was the organizing principle of political modernity. This curiously re-natured view of the nation-state mirrors the modernism it opposes' (Fine and Chernilo 2004: 36). The presuppositions of nationhood and statehood as well as the histories through which both have been linked (as the composite noun 'nationstate' suggests) remain untouched. Cosmopolitanism itself is articulated in opposition to this conventional (i.e. naturalized) and inevitable version of the nation. ${ }^{2}$ Accordingly, nationalism and cosmopolitanism are frequently conceptualized as part of an unchanging zero-sum game. However, 'because nationhood - both conceptually and in practice - is malleable, there is no reason to believe that nations will not be perpetually imagined, even though such imaginings will change in content and form' (Croucher 2003: 2). It is thus not sufficient to recognize that the nation is a historically constructed category (Anderson 1983; Hobsbawm 1990), but essential to explore how exactly this malleability and contingency of nationhood evolves in a global context. Put simply, whereas the constructed nature of nationalism is widely recognized, the national is now naturalized in the sense that the future of nationhood is no longer addressed from a constructivist perspective.

We depart from this naturalized and dualistic orientation by directing attention to the formation of the 'cosmopolitanized nations' as a facet of world risk society. In a first step, we suggest that this figuration is co-extensive with new forms of sociability. More specifically, we propose a new mode of collective identification by differentiating between presumptions of thick belonging and the proliferation of cosmopolitan affiliations. This re-imagination of collectivities is, among other things, circumscribed in the context

\footnotetext{
2. A notable exception can be found in the work of Gerard Delanty. He suggests that cosmopolitanism and nationalism, while in tension, are nevertheless linked producing nations without nationalism in the contemporary global environment (Delanty 2006: 358).
} 
of global norms (e.g. human rights), globalized markets, transnational migrations, embeddedness in international organizations and global risks.

Rather than viewing cosmopolitanism as a normative desideratum, or as anti-thesis to an essentialized version of the national, we contend that cosmopolitization itself is a constitutive feature for the reconfiguration of nationhood. Whereas normative cosmopolitanism is a voluntary choice and often an elite affair, cosmopolitization draws attention to the fact that an increasingly cosmopolitan reality produces side-effects that are often not wanted and even go unobserved. A 'banal' and 'coercive' cosmopolitization unfolds beneath the surface of persisting national spaces. Globalization provides a new context for the transformation of national identifications. And cosmopolitization is the mechanism through which nationhood is re-imagined. Unlike older philosophical engagements with cosmopolitanism as a universalistic principle, the sociological dynamics of cosmopolitization imply an interactive relationship between the global and the local. It is a 'non-linear, dialectical process in which the universal and particular, the similar and the dissimilar, the global and the local are to be conceived not as cultural polarities, but as interconnected and reciprocally interpenetrating principles' (Beck 2006: 72-73).

The aforementioned crisis of territoriality not only recasts which and how collectivities re-imagine themselves, but also carries significant theoretical implications as the spatially rooted understanding of social theory is being challenged by a 'temporal turn'. Accordingly, we examine how nationhood is being recalibrated through the proliferation of imageries that are based on the cosmopolitization of the temporal triad of past-present-future. The absence of a dominant national narrative commanding progress oriented versions of the future produces an open field with a set of competing conceptions of the future. Our findings suggest that cosmopolitanized nations are reimagined through the anticipation of endangered futures. They are re-imagined collectivities based on new forms of affiliation that are, among other things, generated by shared encounters with risk.

Modern collectivities are increasingly occupied with debating, preventing and managing risks. Unlike earlier manifestations of risk characterized by daring actions or predictability models, global risks cannot be calculated or predicted anymore.
Consequently, more influence accrues to the perception of risk, which is largely constructed by media representations of disasters, which as we will show are media(ti)zed through the recasting of these temporal registers. Disasters conventionally signify interruptions. In contrast, in the context of an increasingly interconnected world, they have become limiting cases challenging the taken for granted spatial assumptions of nationhood and its attendant methodological nationalism. Underwriting this proposed reconceptualization of temporalities is the apprehension of global risks as the anticipation of (localized) risks. Specifically, contemporary mediat(iz)ation of risks are reflective of and contribute to new horizons of future expectations. Contrary to previous traditional, religious and statist attempts to provide secure images of the future, the cosmopolitization of disasters engages with insecurities through the global diffusion of risk iconographies. What happens when the past of progress, so to speak, has been discredited in the context of world risk society? How do we experience the temporal triad of past-present-future when the past ceases to be a reliable guide for knowledge of the future? When staged and mediated under what conditions do risks turn into events with a cosmopolitan purchase? Media portrayals of globally shared risk scenarios, we argue, give rise to the emergence of new 'cosmopolitan affiliations of risk'. While the particular meanings ascribed to these risks may differ, they vernacularize cosmopolitan outlooks by their habitual consumption, inevitability and institutionalization.

In the following we explore the conceptual consequences of the aforementioned crisis of territoriality. More specifically, we examine a unique temporal turn characterized by the absence of a future oriented narrative; and how, through the mediatization of risks, collectivities (can) re-imagine themselves in terms of cosmopolitan affiliations. In the second part, we address the persistence of a methodological nationalism in the social sciences and how the reconfiguration of the past-presentfuture triad is challenging these conventional parameters of analysis. We examine this development by tracing different historical conceptions of temporality, with a particular focus on how the proliferation of risks has been undermining the abilities of nation-states to delineate the political and cultural facets of the future. In the third section we demonstrate how these cosmopolitan transformations of nationhood are taking place 
in the context of the emergence of a world risk society regime that marshalls a set of cosmopolitan imperatives. In the fourth part, we zoom in on the central role of media in shaping new outlooks for the future and in providing the foundations for new forms of affiliation.

\section{From National Time to Cosmopolitan Times}

The spatial preoccupation in social theory dates back to sociology's birth amidst the nineteenthcentury formation of nation-states. Ironically, the territorial conception of national culture - the idea of culture as 'rooted' - was itself a reaction to the enormous changes that were going on as that century turned into the twentieth. It was a conscious attempt to provide a solution to the 'uprooting' of local cultures confronted with the formation of nation-states. Sociology understood the new symbols and common values, transmitted primarily through the consolidation of cultural memories by establishing links to foundational pasts, as means of integration into a new unity. The triumph of this perspective can be seen in the way nation space has ceased to appear as a project and a construct and has become instead widely regarded as something natural. These developments are mirrored in a resilient methodological nationalism bound up with the presupposition that the national-territorial remains the key principle and yardstick for the study of social, economic, political and cultural processes (Beck and Sznaider 2006b, 2010; Levy and Sznaider 2010). On this view, the nation-state reflects a 'spatial understanding of the possibility of political community, an understanding that necessarily gives priority to the fixing of processes of historical change in space. Not only does the principle of state sovereignty reflect a historically specific resolution of questions about the universality and particularity of political community, but it also fixes that resolution within categories that have absorbed a metaphysical claim to timelessness. . .. Time and change are perceived as dangers to be contained' (Walker 1990: 172-173). The spatialization of theory is the more remarkable (and regrettable) considering that knowledge and experience are temporal in contexts, and their contextual temporality sets limits to their communicability and translatability into new contexts in new times' (Miller 2008: 8). A reflexive interrogation of the validity of a historically specific and hence contingent national figuration which has been instilled in the sociological imagination by the classical canon is thus needed.

Developing an analytical perspective that escapes this national caging requires not only reflexivity towards the cultural parameters of this national ontology; it also necessitates grasping the emergence of alternative ontological models. A brief historical sketch of changing temporal figurations is instructive as it underscores the need for a cosmopolitan methodology. Conventional western perspectives on changing conceptions of the future address the ideological and institutional transformations of temporality along a series of three epochal strands. Analytically distinguishing between traditional, religious and political dominions over time, the latter is culminating in the modern nation-state. Each of these formations has shaped respective temporal conceptions during a given period.

'At the beginning of human history, the dimension of time itself was under-stood as something mythic. [...] The only way to make mundane existence meaningful was to suffuse it with sacred time through a festive or ritual re-enactment of the events that were presumed to have occurred in primordial time' (Gross 1985: 55). Here time was plotted socially. As Christianity was consolidating its power, time was charted religiously for almost one millennium. By the $16^{\text {th }}$ century political temporality was emerging and challenged both religious and traditional conceptions of time (Gross 1985). The nation-state has since become the dominant institution for the structuration of temporality. National time has been caged as a unifying source and central means for collective mobilization. Benedict Anderson (1983) has shown how the national (secular) state was seeking to establish a functional equivalent to conceptions of religious temporality. Here the past served as a foundational myth based on heroic narratives. The nationalization of time was a central endeavor of the modern state producing empty and homogenous time. And, in its Hobbesian incarnation, the state becomes the provider of the aforementioned ontological security. These modes of temporal structuration were premised on the ability to provide a cultural response to the future and render it intelligible. Both Christianity and nation-states were eager to provide linear notions of deliverance, one anchored in distinctive forms of Salvationism and the other through 
visions of progress. Reinhart Koselleck points out that 'the genesis of the absolutist state is accompanied by sporadic struggles against all manner of control of the future by suppressing apocalyptic and astrological readings of the future. In doing so, it assumed a function of the Old Church for anti-Church objectives' (Koselleck 1985: 10-11). What both, national and religious authority shared was an attempt to monopolize the temporal registers of existence. Theories of progress became the chief prism through which nation-states sought to control the politicalcultural interpretation of the future. The classics of sociology essentially acquiesced to this view (Abbott 2001) by relegating the past and memory practices to tradition(al) societies, thus making room for a presentism - in the double sense of projecting contemporary sensibilities into the past and imposing concerns of the present onto a developing future - that was progressing continuously (be it in the dialectical fashion of historical materialism or the Weberian variant of rationalization).

Contemporary global trajectories, we suggest, have given rise to a fourth temporal epoch that is characterized by fragmented times and the absence of a dominant, let alone, hegemonic conception of temporality and attendant views of futurity. These new temporal figurations bear upon the potential re-imaginations of new forms of collective affiliations. In the absence of a dominant narrative about the future, global risk frames structure how national experiences are informed by global expectations and how global experiences are shaping national expectations. Perceiving the future through the prism of risk perceptions reveals how representations of catastrophes of various kinds (e.g. ecological, human rights) are challenging the ontological security once provided by the temporal narratives of nation-states. However, the result of these developments is not some pure normative cosmopolitanism of a world without borders. Instead, these risks produce a new 'impure' cosmopolitization - the global other is in our midst. What emerges, is the possibility of 'risk collectivities' which spring up, establish themselves and become aware of their cosmopolitan composition - imagined cosmopolitan collectivities' which might come into existence in the awareness that dangers or risks can no longer be socially delimited in space or time.

\section{Cosmopolitan Figurations}

Contrary to the normative universalism of some cosmopolitans, we highlight processes in which universalism and particularism are no longer exclusive either-or categories but instead a codependent pair. Subtending this argument is the notion that meaningful identifications express particular attachments: one's identity, one's biography of belonging, is always embedded in a more general narrative and memories of a group. On this view, particularism becomes a prerequisite for a cosmopolitan orientation. Cosmopolitanism does not negate nationalism; national attachments are potential mediators between the individual and cosmopolitan horizons along which new identifications unfold. A cosmopolitan methodological shift thus elucidates the relationship between processes of actual cosmopolitization and the persistence (or resurgence) of political self-descriptions normatively underwritten by a national framework. It should be emphasized that despite our focus on the nation-state as unit of analysis, we are not reproducing methodological nationalism. Rather methodological cosmopolitanism leaves the question of the unit of analysis open by problematizing it thus providing a new perspective on emerging figurations of collective self-understanding (including neonational reactions).

To understand how past and present narratives of nationhood are related to each other and how the universal and the particular are folded into processes of cosmopolitization, we propose to think about the relationship of the nation-state community to a cosmo-national imagination in Norbert Elias' terms of a 'continuum of changes' (Elias 1992: 46). Rather than subjecting nationhood to another either-or approach stipulating its persistence or its supersession, we suggest that meaningful political-cultural premises are informed by a significant past as well as by a present that is being transformed. On this view, collective modes of identification and the claims that are perceived as legitimate may change over time, however, their respective meanings remain linked 'by a long continuum of changes'. Elias' methodological deliberations on historical processes seem particularly beneficial for the study of epochal change and changing figurations. Figurations form by way of mixing old and new elements. Hence the persistence of older structures (and norms) cannot be interpreted as a mere 
anachronism - as theorists of first modernity did with religion and ethnicity, and cosmopolitan scholars are apt to do with regard to the nation, nationalism and the nation-state. Rejecting any kind of self-sustaining logic of development, Elias instead focuses on the historical and institutional conditions through which cultural and political claims are established and sustained as foundational meaning systems. Their respective dominance is a function of changing figurations. ${ }^{3}$

Elias' figurational sociology assumes that claims of legitimacy are the successful product of a particular development of interdependencies. Those interdependencies cannot be reduced to, say, independent variables, but always remain the very object of our investigation. Figurations thus are webs of interdependence, which tie individuals together and shape their collective self-understandings and the ways in which they articulate times within changing existential coordinates. 'People make up webs of interdependence or figurations of many kinds, characterized by power balances of many sorts, such as families, schools, towns, social strata, or states.' (Elias 1978: 15) What matters for our purposes, is that over time, these figurations frequently mutate into new forms. Villages have become cities, tribal solidarities are absorbed into larger states, cities have become global to name but a few examples for how collectives have been re-imagined in the context of changing social, political and economic interdependencies.

In each case, media representations have played a crucial role in these processes of reimagiNation. The nation-state, at the turn of the 20th century, depended for its coming into existence on a process by which existing societies used representations to turn themselves into new wholes that would act on people's feelings, and upon which they could base their identities - in short, to make them into groups that individuals could identify with. This nation building process parallels what is happening through globalization at the turn of the $21^{\text {st }}$ century. The nation was the global when compared to the local communities that preceded it, however, this did not render it inauthentic. The ability of representations to give a sense to life is

3. It goes beyond the scope of this paper to elaborate on the varieties of cosmopolitan nationhood. Suffice to say, that future research needs to take into consideration that risks are not memory-less but prefigured. Accordingly we need to understand the reconfiguration of nationhood in pathdependent terms. not ontologically but rather sociologically determined. So if the nation is the basis for authentic feelings and collective memory - as the critics of global culture seem to believe almost unanimously - then it cannot be maintained that representations are a superficial substitute for authentic experience. On the contrary, representations are the basis of that authenticity. And there is nothing inconceivable, theoretically and empirically, about them providing such a basis on a global level. How can we apply the concept of imagined cosmopolitan collectivities in a new, expanded form, for exploring the social and political consequences of global risks?

To answer this question it is indispensable to push for a more complex understanding of 'groupness' and the ways in which multiple forms of identification can co-exist or conflict. Much of the debate on cosmopolitan orientations is circumscribed by a narrow understanding of belonging which is, no doubt, compounded by the vagueness the notion of identity elicits (Brubaker and Cooper 2000). Strong forms of belonging, such as communitarianism and ethnic nationalism, are usually based on a naturalized image of the nation. Cosmopolitanism, by contrast, is frequently characterized (by both its normative champions and nationalist opponents) as the breaking down of boundaries: people associate freely, unmediated by blinkered categories of nationhood. Underlying this dualistic notion is an assumption that belonging operates primarily, even exclusively, in the context of communal allegiances expressing thick solidarities. However, as Craig Calhoun has pointed out, we ought not succumb to the opposite fallacy either, which presents cosmopolitan identity 'as freedom from social belonging rather than a special form of belonging, a view from nowhere or everywhere, rather than from particular social spaces' (Calhoun 2003: 532). Calhoun's (2007) critical engagement with the nexus of cosmopolitanism and nationalism has yielded important insights. According to Calhoun 'cosmopolitanism is neither a freedom from culture nor a matter of pure individual choice, but a cultural position constructed on particular social bases and a choice made possible by that culture and those bases" (Calhoun 2003: 544). In our view, the cosmopolitization of these bases becomes a readily available complement and source for the reconfiguration of the national (not its alternative). Ultimately, at both the national and cosmopolitan level, successful identifications 
with distant others are predicated on a balance between immediate attachments with concrete others (e.g. kin, local) and thickening versions of solidarity with distant others (e.g. the nation, the global). For Bruce Robbins (1998) this is neither a matter of detachment or simple attachment. Instead cosmopolitan affiliations consist of multiple attachments driven by re-attachments and long-distance attachments.

This leads us to interrogate how these new forms of sociability arise. Interdependencies are an essential ingredient, but they are neither consensual nor territorially caged. There is a common exposure to risks. What is shared, however, is not so much the meanings ascribed to these risks but the simultaneous exposure.

As long ago as 1927 John Dewey was already asking 'for conditions under which a Great Society may become a Great Community'. He distinguished between collectively binding decisions on the one hand and their consequences on the other. He linked this to the theory that a public sphere only ever emerges at the focal point of public communication, not out of any general interest in binding decisions but, rather, as a result of their consequences. People remain indifferent to political decisions as such. It is not until they begin to communicate with one another about the problematic consequences of decisions that they wake up. It is this communication that shakes them out of their complacency and makes them worry. It shakes them out of their indifference, creating a public sphere and a potential collectivity of action. In our language, it is global risk - or, more precisely, the staging and the perception of global risk - that creates imagined collectivities across all kinds of boundaries. It is the reflexivity of world risk society that produces the reciprocal relationship between the public sphere and globality.

\section{Creating the Cosmopolitanized Nations: The World Risk Society Regime of Transformation}

There is not one universal process of cosmopolitization, we argue, but there are varieties of cosmopolitan trajectories. Those varieties cannot be identified on the national level, they have to be conceptualized on a global level related to the theory of world risk society. The world risk perspective focuses on global institutional factors and transformation processes, exploring how global principles penetrate societies. How does the social construction of global risks propel the cosmopolitization of the national? In what follows, we present some of the global dynamics explaining why and how nation making and world making are actively mixed from within national settings.

We briefly illustrate the emergence of this world risk society regime in seven points.

1. The human rights imperative

2. The world market imperative

3. Migration as the prism for Otherhood ('The global Other is in our midst')

4. Global generations and civil society movements

5. Local interpenetration of world religions

6. Shifting global power structures or the decentralization of the centre

7. Cosmopolitan realism

\section{The human rights imperative}

Cosmopolitization has an intrinsic affinity to human rights or, to be more specific, to the national abuse of human rights. The political will of nation-states to legally engage with memories of rights abuses is a central factor for their legitimate standing in the international community and increasingly also a domestic source of legitimacy. This finds its expression in an increasingly de-nationalized conception of legitimacy, which results in a cosmopolitization of sovereignty. While states may retain some of their sovereign functions, their legitimacy is no longer exclusively conditioned by a contract with the nation, but also by their adherence to a set of nation-transcending human rights ideals (Levy and Sznaider 2006b). Human rights norms are a key site for the active national incorporation of cosmopolitan imperatives into national consciousness and the transformation of national self-definitions. Exclusionary aspects of national citizenship are partly unbundled and complemented with a cosmopolitan legal injunction that commands the equal treatment of humans as others (Soysal 1994).

To be sure, a top-down institutional approach only provides limited inferences on how much of this cosmopolitan transformation of the judicial 
sphere actually trickles down to society. How meaningful it is for the lives of individual citizens and whether they espouse the cosmopolitan values promulgated at the state level remains subject to additional studies (Levy, Heinlein and Breuer 2011; Mau, Mewes and Zimmermann 2008; Calcutt, Woodward and Skrbis 2009). Notwithstanding, juridification should not be treated in a narrow legal frame, but as a socially embedded, meaning-producing act. Law has jurisgenerative power. Law also structures an extralegal normative universe by developing new vocabularies for public claim making, by encouraging new forms of subjectivity to engage with the public sphere, and by interjecting existing relations of power with anticipations of justice to come (Benhabib 2009: 696).

On this view, the legal domain is not only about the institutionalization of universal claims on which nation-state sovereignty and the selfunderstanding of a political community rest but it also figures as a strategic site of their transformation (Held 2002).

Trials, in particular, are the venue for transformative opportunities, where memories of grave injustices are addressed in rituals of restitution and renewal (Osiel 1997). Justice itself becomes a form of remembrance (Levy and Sznaider 2006a). And 'the growing importance of pursuing retroactive justice is also a result of the increased valorization of memory as the essential element of collective identity' (Misztal 2001: 63). Beyond the potential of trials to create legal precedents, their public dramaturgy also attracts widespread media attention. Dramatic enactments ensure that human rights trials not only change the law from within, but that they enjoy ritualized attention, thus serving broader educational and moral purposes (Savelsberg and King 2007). Human rights trials thus exemplify the world making of the national from within.

Perhaps less intuitive is the second dimension where human rights contribute to the cosmopolitization of nationhood - namely the emergence of 'new wars' (Kaldor 2007). Why do those 'new wars' ('military interventions) contribute to the creation of cosmopolitanized nations? There are two reasons for this: First the military force is multi-national in itself and the same holds for its management. Thus it is within the national context that the new historical type of a 'cosmopolitan soldier' of all ranks is being created.
Second - it is a 'postnational war' (Beck 2006), characterized by the blurring and combining of basic distinctions which are constitutive for wars between nation-states. The either/or is replaced by both/and - both war and peace, both national interest and cosmopolitan responsibility, both police and military. The defence of human rights on foreign soil highlights the cosmopolitization of the national in particular.

How should we, for example, categorize the Kosovo 'conflict' in which NATO (without UN mandate but with the consent of a majority of European peoples and governments) flew bombing raids to prevent a genocide in the former Yugoslavia? What made the NATO attack on Yugoslavia so confusingly (il)legitimate could easily lead to the normalization of a new kind of war. This war is postnational, because it is neither conducted in the national interest - 'the continuation of politics with other means' - nor can it be understood in terms of the old rivalries of more or less hostile nation-states. Rather, cosmopolitan responsibility makes postnational war possible by annulling the restriction on the responsibility of states to their national territories and their lack of responsibility beyond national frontiers. Human rights must be guaranteed and enforced beyond the boundaries of sovereign nation-states, as well as within individual states and possibly against their resistance. The unlimited sovereignty of sovereign states, which made classical war between states possible, makes the enforcement of human rights impossible. Only if the principle of state sovereignty is restricted can the validity of human rights be assured against violations of civil rights by governments. States are no longer the sole legal subjects of cosmopolitan law but also individuals whose rights must be protected by superstate authorities against 'sovereign' states. The resulting 'post-wars', postnational both-wars-and-not-wars, break with the national state-against-state warfare.

\section{The world market imperative}

The unbundling of nationhood through global capital, transnational production processes, and transnational institutions of commercial law is again a major transformation of active self-cosmopolitization of the nation-state. Deregulation is a vehicle through which states are incorporating the world market regime and guaranteeing the rights of global capital as an essential ingredient of the national. 
'No one can do politics against the markets'. Joschka Fisher's dictum was emblematic of the self-image of the political class over the past two decades. The politicians saw themselves as pawns in a power game dominated by globally operating capital. Here we are dealing with a self-delusion of unpolitical innocence in a twofold sense: On the one hand, it glosses over the fact that the political class brought about the alleged powerlessness to act itself through its own conduct. Specifically, it imposed the rules of the globalized markets at the national level under the banner of 'reform policy', thus giving rise to the allegedly no longer controllable financial world risk capitalism. Note that global capital acquires its 'unchallengeable' power only when national politics actively colludes in its own self-abolition (Beck 2012).

On the other hand, the self-inflicted impotence of politics serves as a convenient excuse to deflect the pressure to act within global domestic politics and not to make use of the opportunities for action that are opening up. The argument runs as follows: Since there are no consensual global political answers to the consequences of globalization, there's nothing to be done?

\section{Migration as the prism for Otherhood ('The global Other is in our midst')}

In the current academic climate, where nationalism is often discussed as a right-wing patriarchal ideology, this is a widely accepted account of cosmopolitanism: cosmopolitanism is good and nationalism bad for human values and rights. Against this either/or account we must understand that cosmopolitanism grows out of nationalism. Without nationalism there will be no really existing cosmopolitanism.

The same is true with economic globalization. Without global capitalism there will be no cosmopolitization. Cosmopolitization is the sociological face of globalization. Already Marx and Engels captured this nexus in the opening paragraphs of the Communist Manifesto:

'The bourgeoisie has through its exploitation of the world market given a cosmopolitan character to production and consumption in every country. To the great chagrin of Reactionists, it has drawn from under the feet of industry the national ground on which it stood. [...] In place of the old local and national seclusion and self-sufficiency, we have intercourse in every direction, universal inter-dependence of nations. [...] National onesidedness and narrow-mindedness become more and more impossible...' (Communist Manifesto)

As greater economic interdependence is fostered among countries through trade and investment, a transnational space is created for the circulation not only of goods and capital, but for the cosmopolitization of labour as well. Cosmopolitization through migration is here created by the systematic link between labor emigration and development and its institutionalization through national state policy with the sanction of international bodies. While migration is not a new phenomenon, older assimilationist trajectories have given rise to multicultural conceptions where the 'other' is, at least, normatively validated. The feminization of labour migration is one example of the large scale, even if uneven, interaction of different cultures which involves the increasing migration of women from poorer countries to the growing international demand for workers to fill low-status 'feminized' occupations - nannies, caretakers for kids and older people, workers in restaurants and hotels and so on. Many of these demands are generated by another gender dynamic within high growth nations: the entry of middle-class women with sufficient training into white collar employment at the same time that the surplus of young female labour, traditionally the resource of paid domestic work for middle-class households, has been completely absorbed into industry and other non-domestic services. Thus middle class families and households the world over have been cosmopolitanized: the global other works in their midst.

If the transformation of solidarity and modes of social exclusion is the threshold for measuring the extent to which a nation is cosmopolitizing, the question arises what the measure-stick for the engagement with the other consists of. The ultimate immediate encounter with the other and diversity is primarily channelled through the experience of migrants and thereby the proliferation of cosmopolitanized nations (as an objective fact rather than the heated and misleading debate about its ideological penchant of multi-culturalism).

\section{Global generations and civil society movements}

From Arab uprisings to protests in Athens, Barcelona, even middle-class movements challenging 
capitalism in Washington and democratic movements challenging authoritarian power in Moscow - all of these civil society actors have three features in common: first, they come as a surprise, which means, they are beyond political and sociological imagination; second, they are transnational or global in their scope and consequences; and third, they are centred on issues of justice, equality and human rights using the virtual electronic space of the internet, a powerful site for transforming and re-imagining the national. Consequently, the idea of generations isolated within national boundaries is historically out of date. What we are observing is the rise of 'global generations' (Beck and Beck-Gernsheim 2009), the deepening of generational gaps and conflicts at the same time inside and across national borders, through which cosmopolitanized nations are being conflictfully re-created.

Civil society movements constitute (il)legal, (il) legitimate breeds that operate in both highly legitimate and highly precarious ways within national and transnational power spheres. The extraordinary legitimation capital they posess cannot be compared with that on which their competitors - states, global capital - can draw. Civil society movements are, after all, the entrepreneurs of the cosmopolitan commonwealth. They not only develop the categories in which global issues of poverty, human rights, women's rights, justice, climate change etc., are formulated; they also place them in practice on the political agenda, both at the national and the global level.

Moreover, the national egoism of states and the 'profit-egoism' of mobile capital become recognizable as national egoism and profit-egoism, enhancing a need of justification, within the cosmopolitan horizon and expectations in and on which civil society movements and global generations operate. In this way, with the success of their transnationalized network actions, civil society movements inculcate an opposition that is utterly unthinkable within the horizon of the nation-state.

Of course, these civil society movements are not a one-way street, but the full range of the social forces will use its power, from fighters for human rights to political and religious fundamentalists. Global civil society becomes a democratic space for many opposing views including a range of anti-cosmopolitan uses as well.

\section{Interpenetration of world religions}

Why is the omnipresence of world religions such an important feature for the cosmopolitizationof nationhood? In the new communicative thickness of the world, the non-comparability of religions based in national cultures and territories is coming to an end. As Nietzsche foresaw, at the beginning of the $21^{\text {st }}$ century, we are living in an 'age of comparing' where all religious believe systems are in one way or the other present in all locations of the globe. That fact - a shared present and universal proximity - creates new forms of coexistence, interpenetration, resistance and conflict among world religions. The 'religious other' is in our midst (Beck 2010).

Where does the potential of conflict and violence come from? By committing themselves to universalism, the world religions create a hierarchy of superiority and inferiority which results in a radical otherness. This occurs because it is rooted in a dualism of believers and unbelievers, not as a preexisting fact but to be understood as a consequence of choice, ascribable to individuals. This means the distinction between 'we' and 'others' fuses with the distinction between Good and Evil.

Under the impact of this process, the universalist claims of Western modernity, like those of Christian revelation, find themselves exposed to criticisms. This is achieved, on the one hand, by decoupling modernity from Westernization, since this denies the West its monopoly of modernity. On the other hand, the certitudes of Christian revelations are forced to confront the certitudes of the revelations of Islam and other faiths. The result is that the necessity to compare the different religious faith under conditions of their mutual interpenetration ends up in an everyday clash of religious universalisms.

This state of affairs is reflected in the growth of transnational forms of life in which comparisons between the world pictures of the various religions and discussions of their relevance in everyday life act as an existential stimulus. This cosmopolitan constellation apparently transforms nationally defined territories into cross-border battlefields of world religions with a worldwide reach and communicative echo effects (see for example the Danish 'controversy about the caricatures of Mohammed'). 


\section{Shifting global power or the decentralization of the centre}

Perspectives on the cosmopolitization of the nation have thus far ignored the question of the influence of de-colonization on the disempowerment of the centre. Here, too, it is the victories of modern, industrial capitalism and its effects - global risks, crises and geopolitical shifts, especially since 1989 - that call into question the bases of nation-state orders and powers both inside and outside the old West. Thus we have to look at the centre from without.

From the perspective of the developing countries, however, the current picture of the centre is informed by a shift in power in favour of postcolonial, developing countries (reflected in their participation in the new G-20 meetings, for example); a shift in the global economic geography of power from the Atlantic to the Pacific; and the steady de-monopolization of the US dollar as the leading global currency in favour of a conglomeration of different currencies and bilateral currency treaties. In addition, there is the growing importance of South-South and East-South partnerships for solving economic problems, not to mention the loss of moral authority and exemplariness of the former Euro-American centre. This indicates that the centre-periphery polarity has given way to a different fault line that runs between surplus and deficit countries or between creditor and debtor countries, thus shifting the dominance of the West by giving room to a script of 'emancipatory multipolarity' (Nederveen Pieterse 2011).

\section{Cosmopolitan realism}

In world risk society national realism has become a backward oriented idealism which ignores and contradicts the condition of the cosmopolitanized nations. And national realism has only insufficient answers to global risk challenges. Therefore, the maxims of national realpolitik, which holds that national interests have to be pursued by national means, must be replaced by the maxims of a cosmopolitan realism, namely the more cosmopolitan the political structures and activities, the more successful they are in promoting national interests and the greater the weight of national structures in world risk society (Beck 2005, 2009; Beck and Grande 2010b).

Cosmopolitan realism calls for neither the sacrifice of one's own interests, nor an exclusive bias towards higher ideas and ideals. On the contrary, it accepts that for the most part political action is interest-based. But it insists on an approach to the pursuit of one's own interests that is compatible with those of larger entities. Thus cosmopolitical realism basically means the recognition of the legitimate interests of others and their inclusion in the calculation of one's own interests. In this process, interests become 'reflexive national interests' through repeated joint strategies of selflimitation; more precisely, empowerment arises from the cosmopolitan redefinition of national interests which national realism essentializes. To be sure, there are often limits and dilemmas to cosmopolitan realpolitik. It is no panacea for all the world's problems and it by no means always works. However, cosmopolitan realism could become the political philosophy/ideology of the less powerful nations which advocate the cosmopolitan imperative - cooperate or fail! - in order to bind dominating powers by 'golden handcuffs'.

Cosmopolitization accentuates this cosmopolitan imperative which no state can avoid, without endangering its own interest in survival. The imagined collectivities of risk are imposed, they are not based - as cosmopolitanism seems to imply - on voluntariness, choice, an elite status, normativeness and philosophical insight. The cosmopolitan risk collectivity is precisely not based on the insight, that we are all members of a community of humankind. What might be called the 'good Samaritan effect' is not sufficient: that is, that in a Christian or cosmopolitan exercise of neighbourly love we act in solidarity with others who are vulnerable, suffering, whose humanity is threatened or being destroyed. Instead it is we who are forced, in our own most pressing interest in survival, not only to address those distant others, but to come together with them in order to devise a new kind of collectivity. In other words, cosmopolitanized collectivities depend on realism and not simply on sympathy, regret and pity for the suffering of others (Beck 2011). How can strangers - constructed as members of imagined national communities - become part of a new web of affiliation? Or to put it differently: How can 'thin cosmopolitanism' be replaced by 'thickening cosmopolitan affiliations'? 


\section{Media(tion) and the ReimagiNation of Cosmopolitan Risk Collectivities}

We address these questions by focusing on the seminal role of the media in producing new frameworks of identification. First we offer an alternative conceptualization of how cosmopoli$\tan$ horizons are formed. Next we show how the contemporary mediatization of risks and futurity produce a new meaning-making environment providing the foundation for shared cosmopolitan expectations.

As the current age of uncertainty is deprived of modular pasts and aspirational futures, risk perceptions are resituated in new forms of manufactured insecurities and related temporal modalities. The linkage between risk perception and mediatized disaster representations is not incidental but intrinsic to each. Risks are social constructions and definitions based upon corresponding relations of definition. Their 'reality' can be dramatized or minimized, transformed or simply denied according to the norms which decide what is known and what is not. They are products of struggles and conflicts over definitions within the context of specific relations of definitional power, hence the (in varying degrees successful) results of stagings (Beck 2009: 30). The more obvious it becomes that global risks cannot be calculated or predicted, the more influence accrues to the perception of risk. What is perceived as dangerous is not only a function of cultural and social contexts but also of an issue's career of media representation and social recognition. Perceptions of risk thus arise out of individual latitudes and risk estimations in perpetual interplay with institutional discourses. In world risk society, the central question of power is a question of definitional authority (Beck and Kropp 2007). We shall later see that the power of the media to address/thematize/represent risk is largely contained in its agenda setting function and the fact that certain issues are largely ignored (e.g. chronic/structural features of climate catastrophes). Instead, much of the agenda setting function is driven by a focus on disasters that carry the requisite features of media events. The main point here is that it is wrong to regard social and cultural judgments as things that only distort the perception of risk.
Without social and cultural judgments, there are no risks. It is those judgments that constitute risk.

These judgments are by now firmly embedded within a media ecology that has global reach. Media research shows that disasters are registered, culturally defined and assume their meanings through an ongoing communication flow (Cottle 2009). On this view, media not merely represent disasters but help constitute them. We can speak here of global media events-GME (Ribes 2010), which are critical in defining catastrophes and mobilizing actors. 'GMEs are very much present in daily routines because they call our attention long before they occur, there are always people engaged in one or more of them, and, finally, when one event concludes another will begin' (Ribes 2010:5). They may depend, among other things, on how disasters are mediat(iz)ed and locally appropriated in the context of world risk society.

Paradoxically, the global media(tiza)tion of risks also provides new temporal narratives intended to alleviate our anxieties about the future. In the absence of a self-confident disposition toward the past and a widely shared vision of the future, risks are now enmeshed in an age of post-catastrophy via the principle of premediation. As Richard Grusin has pointed out: 'Where remediation characterized what was 'new' about new media at the end of the twentieth century as its insistent remediation of prior media forms and practices, premediation characterizes the mediality of the first decade of the twenty-first as focused on the cultural desire to make sure that the future has already been pre-mediated before it turns into the present (or the past)'(Grusin 2010: 4). It is not in spite but precisely because of the uncontrollable nature of risks that premediation is culturally so appealing. The exception no longer tests the rule but it is the breach itself that is being routinized and ritualized through the pre- and remediation of GMEs.

Premediation differs from remediation in that it is no longer concerned with earlier questions about the authenticity of representation. Nor should it be confused with the prognostic ambitions of earlier times. 'Premediation is not to be confused with prediction. Premediation is not about getting the future right, but about proliferating multiple remeditations of the future both to maintain a low level of fear in the present and to prevent a recurrence of the kind of tremendous media shock that the United States and much of the networked world experienced on 9/11' (Grusin 
2010: 4). Non-knowing here is not merely a sideeffect but a prerequisite for envisioning the future as 'premediation imagines multiple futures which are alive in the present which always exist as not quite fully formed potentialities or possibility. These futures are remediated not only as they might become but also as they have already been in the past. [...] Premediating the future entails remediating the past' (Grusin 2010: 8). As such, it provides what Grusin refers to as an 'affective prophylaxis' to the existential and scientific status of non-knowing. Risk refers to a future that needs to be prevented. The pluralization of time differs from earlier attempts to control the future, even if the basic impulse to manage the future might be similar. "Clearly the current expression of premediation in televisual new media and film bears some affinities to the traumas of modernity, particularly to the preoccupation with predicting and controlling the future attendant upon the increased risks and consequences of industrial accidents in modernity. Developments like insurance, political polls, or economic forecasts, for example, are in some sense, early effort to premediate the future. Yet they differ from the current logic of premediation in their desire to control the future rather than to proliferate competing mediations of it' (Grusin 2010: 157). Moreover, they are operating in a fragmented media ecology (Cottle 2009) that supplies a plurality of affiliations with others.

The burgeoning literature on the cosmopolitization of media images has focused on how meaningful the other is and what degree of empathy and compassion such images produce (Robertson 2010; Silverstone 2007; Urry 2000). These projects have yielded a wide array of results ranging from claims that this global iconography of 'distant suffering' (Boltanski 1999; Wilkinson 2012) has generated significant attention (Höijer 2006; Kyriakidou 2009), produced awareness to the misery of others (Chouliararki 2006; Tester 2001) as well as reverse claims about 'compassion fatigue' (Moeller 1999). Regardless of how we evaluate these findings, they share a number of presuppositions. How extensive and intensive contemporary collectivities of solidarity actually are and what the mechanisms for an engagement with the other consist of remains to be specified. To be sure, this qualification is not restricted to cosmopolitan identifications. It is, for instance, not clear how a comparable set-up focusing on attention to the other within national boundaries would fare. How do nationals respond when they are confronted with the misery (e.g. chronic unemployment, poverty) of their fellow-nationals? While this essay cannot possibly answer all these questions, we would like to direct attention to the role of the media in producing new forms of connectivity. What is the threshold of collective identification - be it local, regional, national or global?

Most cosmopolitan (and general) approaches about the capacity of the media producing moral sensibilities vis-à-vis others are predicated on assumptions of audience attentiveness and active involvement. Paul Frosh challenges this 'attentive fallacy'. Instead he emphasizes 'the work of 'phatic morality', the moral ground created by long-term, habitual, ambient forms of mediated connectivity...' (Frosh 2011: 383). Contrary to the equation of attentiveness and empathy, Frosh argues that 'television is in part morally enabling because of forms of inattention and indifference that frequently characterize relations between the medium and its audience, as well as between viewers and viewed'(Frosh 2011: 385). Accordinglyaudience inattention is not a deficiency but a necessary condition for what he calls 'mediated sociality:' 'one can disengage from media texts without relinquishing connectivity - without severing the links to others and to 'the social' that television routinely enables and symbolizes' (Frosh 2011: 384). What matters here then is less the hard to measure and often presumed attentiveness, but rather the extent to which viewers become habituated to certain types of (global) media events. 'But it is not the paying of particular attention to specific programs that constitutes the ground of audiences' experience of mediation, but the presence of media perpetually in attendance in our lives and intimate spaces, available when needed to be of service' (Frosh 2011: 384). This line of thought is closely aligned to the abovementioned literature on agenda setting functions which has long dispelled Orwellian and Marxisant assumptions about control and hegemony. Instead of reducing the impact of the media to the notion that they tell us what to think, agenda setting and its correlate of habituation suggest that the ideological power of the media consists in telling us what to think about. Whether cosmopolitan collectivities are formed ultimately depends on how risks are mediated and consumed as habituated practices. 
The effects of global exposure and habituation need to be explored further. Current research shows that the production of global media images are recontextualized through national broadcasting frames (Clausen 2006) and their consumption is prefigured by national cultural inflections (Fairclough 2006). Kyriakidou succinctly states that 'media are more than technologies or media discourses; they also entail practices, most importantly the practices of the producers of media content and of their audiences, which are embedded within specific social, cultural, historical, and economic contexts. [...] Mediated cosmopolitanism as the mediated expansion of social imagination beyond the local and the national is dependent on these practices, technological and discursive, and cannot be taken for granted on the basis of the global dissemination of media cultural products' (Kyriakidou 2009: 485-486). Kyriakidou's research is an important contribution to the burgeoning field of cosmopolitan research. Yet like so many other scholars operating under the global umbrella she too reverts to a binarism that is problematic when she concludes: 'The discussion here has illustrated how audiences draw alternatively upon national discourses and cosmopolitan ideas in making sense of distant suffering' (Kyriakidou 2009: 493). This assessment is underwritten by the either-or logic which reproduces a static conception of national identification and minimizes the salience of multiple and thickening affiliations.

Cosmopolitization carries transformative effects for the inner grammar of cultural and national identifications themselves. More generally, a cosmopolitan perspective seeks to overcome the habit of theorizing globalization in an either-or logic predicated on oppositions in the mold of inside-outside or exogenous-endogenous (Beck 2006). Cosmopolitanism, as an analytic paradigm, highlights the emergence of new social spaces and imaginaries through their very interaction. The extent to which the cosmopolitan makes claims on distant identifications remains an empirical question and subject to the emerging web of affiliations. The main interpretive point here is that even if particular cultural orientations are prefiguring how GMEs are decoded, these very national outlooks are not necessarily or likely to be the same as earlier incarnations of nationhood. GMEs do set the agenda and create the potential for phatic morality as a foundation of cosmopolitan risk collectivities. However, the degree of habituation is not the result of shared interpretations of global risks but rather of the shared exposure and consumption of media events themselves.

\section{Outlook}

In this article we have dealt with reimagining nationhood in terms of how the mediation of global risks is changing the sense of national belonging. The transformative power of global risks is expressed in the twin processes of deconstructing and reconstructing. Rather than viewing cosmopolitanism as alternative or even anti-thesis to a naturalized version of the national, we have argued that cosmopolitization itself is a constitutive feature for the reconfiguration of nationhood. We have delineated the features of cosmopolitan nationhood in the context of world risk society. The latter is characterized by regimes of cosmopolitization circumscribed by: (1) the human rights imperative; (2) the world market imperative; (3) migration as the prism for Otherhood ('The global Other is in our midst'); (4) global generations and civil society movements; (5) local interpenetrations of world religions; (6) shifting global power structures or the decentralization of the centre; and (7) cosmopolitan realism. We have treated the catastrophic global risk potential as compulsive force, in terms of actors having to respond to this global situation (varieties of cosmopolitization). Thus in the absence of clear secular, and nation-state driven visions for the future, most contemporary societies are involved in various forms of risk management (including the denial of global risks). However, unlike earlier manifestations of risk characterized by daring actions or predictability models, global risks cannot be calculated or predicted anymore. Modern collectivities are increasingly pre-occupied with debating, preventing and managing unknowable risks (manufactured uncertainties), which cannot refer to past experiences. Accordingly, more influence accrues to the perception of risk, largely constructed by media representations of disasters.

Whereas national heuristics have treated (global) risk as temporary, pathological and residual, cosmopolitan heuristics approach risk as central and constitutive. This shift is characterized by a transition from homogenous national time to cosmopolitan times that are fragmented and contingent. It is, thus, not merely the pluralization of temporal conceptions, but the fact that these 'mixed 
times' underwrite the normative validation of 'other' times (and times of the other). While 'mixed times' are not necessarily new (religious and statist attempts to shape temporality have been competing for primacy for a long time) they are now co-extensive and a legitimate feature of cosmopolitan realism.

To be sure, we are still in the midst of these cosmopolitan changes, and many issues remain openended.We thus would like to conclude by briefly sketching three areas that require further attention.

First, if we accept the assumption that cosmopolitanism can only thrive if it provides an answer to the ontological insecurity that characterizes the crisis of the national, then the following questions become fundamental: What are the conditions for and against the creation of ontological security inscribed into cosmopolitanized nations? What does this mean if we think of cosmopolitanism along the lines of the four epochs we are discussing? Is each of these epochs a selfconscious engagement/response to the dominant system that proceded it? In the traditional model this is accomplished, among other things, through a cyclical approach and the power of recurrent rituals.

The religious model gets rid of the cyclical approach but is eager to provide a teleological narrative, also underwritten by rituals (thus retaining some cyclical dimension), that provides answers to both (depending on which religious sect you chose this can be taking place in the here and now or projected into the future).

The national model recognizes the need for ontological security and the future by focusing on modern nationalism and a new teleology - i.e. progress.

The cosmopolitan model emerges and contributes to the ontological crisis and future visions on the background of world risk society. In order to succeed cosmopolitanism too needs to build on a set of pre-existing meaning systems (and transform them without losing track of their 'function') and attendant visions of the future.

Looking at it this way, the open question is: how can world risk society (as an objective phenomenon, based on regimes of cosmopolitization) be understood in the context of a competing set of orientations (probably the religious mode is the most powerful one today with the diminishing response national tropes enjoy) to create conditions of certainty, stability and prospectivity? The context of world risk society does not mean these securities can be dispensed with. Giving rise to the following paradox: how, in the context of world risk society, can the transformation of calcubale risks into manufactured uncertainties be combined with the creation of cosmopolitan ontological securities? How can the old certainties of thick belonging and homogeneity give way to new affiliations and diversity? Put differently, while we can attribute many transformative qualities to cosmopolitization (both from the observer and the actor perspective) we also need to think about the conditions of possibility for its routinization and naturalization.

The bottom line here is that unless one tackles this deliberately, we, cosmopolitan scholars might face the same fate as early Marxists who perceived of Marxism as a main tool to explain social change, when in effect its elaborate understanding of power made it into a valuable explanation for how the social order was reproduced (driven by the question of why the expected change, revolution, did not materialize).

Second, the national has no longer the legitimate authority to determine the future, let alone sole control over it. How then can cosmopolitan figurations in world risk societies become co-extensive with new forms of sociability? More specifically, how can we differentiate between assumptions of thick belonging and the proliferation of cosmopolitan affiliations? How can cosmopolitization, embedded within structural manifestations such as individualization (Beck 1992; Beck and BeckGernsheim 2002; Chang and Song 2010; Suzuki et al.2010; Yan 2010) and risk capitalism, provide a new context for the transformation of collective identifications and the re-imagination of nationhood? These new collectivities are neither traditional nor voluntary. Instead they are affiliations imagined under conditions of interdependencies imposing collective constraints. Ultimately the political and cultural salience of these cosmopolitan affiliations depends on how risks are mediatized and consumed as habituated practices. Here sociability is not established under conditions of united interpretations but as a result of shared attentiveness to global risks.

In the absence of teleological futures and in the face of unknown risks, questions of collective survival constitute shared concerns. If Georg Simmel (2004) conceptualized first modernity as a 
web of affiliations envisioned as concentric circles (from kin to nation), second modernity is characterized by intersections (where individualization, national identification and cosmopolitization are mutually constitutive). To be sure, collectivities do not have the same perceptions of future risks, but they are articulating their affiliations in the context of various imperatives marshaling shared cosmopolitan horizons of expectations. These can, of course, be resisted, but they nonetheless have become the global measure stick for how futures are engaged.

Whereas cosmopolitanism has served us well as a sensitizing concept, directing our attention to cosmopolitization as an operationalizing concept moves us ahead and opens avenues for future research. As we have noted above, cosmopolitization is 'coercive' in that it transforms the experiential spaces of nation-states from within often against their will, beyond awareness, parliamentary elections and public controversies, so to speak as a side effect of flows of migration, consumer choices, tastes in food or music or the global risks that tyrannize everyday life and transform the experiential spaces of the nation-state from within. This is what sparks political conflicts, specifically when cosmopolitization (potentially) explodes taken-for-granted understandings and intuitions of national society and politics which have become second nature. All conflicts sparked by cosmopolitization, regardless of the level at which they are located and whether the parties are powerful or powerless occur in the shadowy space of illegitimate legality or illegal legitimacy because they break with the nation-state order and sometimes even law (Beck 2006). Thus the conflict-laden dialectic of cosmopolitization enforces anti-cosmopolitization - and vice versa!

But what might lend opposition to cosmopolitization its superior power? The answer is that cosmopolitization (a) occurs in a latent fashion and (b) is an analytical and political provocation to the nation-state order, developing as it does under the suspicion of disloyal and illegal legality. Cosmopolitization seems unreal because it takes place outside the field of vision of old categories. What remains national? Thought. What is no longer national? Reality! Cosmopolitization is a compulsory re-education programme in openness to the world. And like all forced learning it can and often does meet with a stubborn insistence on 'my country right or wrong' nationalism. The national world resists the school of cosmopolitization with all its might. It resists the instruction of cosmopolititzation, it can and must ignore it, because cosmopolitization is such an overbearing taskmaster against which collective resistance seems justified as a general rule.

Regardless of how cosmopolitization unfolds and what kind of reaction it triggers, we must be attentive to the fact that perceptions of risk are path-dependent and involve varieties of cosmopolitanism (Beck and Grande 2010a). However, our exploratory comments suggest that the mediatization future risks is a key part in worldmaking processes of the national.

Third, these processes raise questions of 'methological cosmopolitanism' (Beck 2000; 2006; Beck and Sznaider 2006) as such, especially with regard to the relation between theory and empirical data: The cosmopolitan turn in the social sciences requires a new kind of middle range 'descriptive social theory' that opens up the empirical dimensions of the cosmopolitization of nationhood. This also implies that, based on empirical research, the task will often be one of creative concept-generation 'opening up lines of inquiry that encourage a rethinking in historical time, of the relationships among observation, the object of study, and the analytical instruments used' (Werner and Zimmermann 2006: 45). Accordingly, the methodological problem becomes one of mediating between actor and observer perspectives - and thus knowing when, as an observer, one makes descriptive or prescriptive statements (e.g. do actors actually experience a compulsion to respond to cosmopolitization?). The problem is that the actor-observer distinction is itself part of the observer perspective - we never really get to the 'actor's actor' perspective. Still, we need to create conditions in which to put the theory to an empirical test - and be open to possible falsifications of theoretical expectations.

What is our postion as social theorists and sociological researchers in this highly contested process of transformation? Is there an opportunity to reinvent sociological enlightenment to comment on the coming of cosmopolitanized nations and their enemies? 


\section{References}

Abbott, A. (2001) Time Matters: On Theory and Method. Chicago: Chicago University Press.

Adam, B. (2008) 'Future Matters: Futures Known, Created and Minded', $21^{\text {st }}$ Century Society 3(2): 111-116.

Anderson, B. (1991) [1983] Imagined Communities: Reflections on the Origin and Spread of Nationalism. London: Verso.

Appadurai, A. (1996) Modernity at Large: Cultural Dimensions of Globalisation. Minneapolis: University Minnesota Press.

Appiah, K. A. (2006) Cosmopolitanism: Ethics in a World of Strangers. New York: W. W. Norton.

Beck, U. (1992) Risk Society: Towards a New Modernity. London: Sage Publications.

Beck, U. (2000) What is Globalization? Cambridge, UK/Malden, MA: Polity Press/ Blackwell Publishers.

Beck, U. (2002) 'The Cosmopolitan Society and its Enemies', Theory, Culture \& Society 19 (1-2): 17-44.

Beck, U. (2005) Power in the Global Age: A New Global Political Economy. Cambridge, UK/Malden, MA: Polity Press.

Beck, U. (2006) The Cosmopolitan Vision. Cambridge UK/Malden, MA: Polity Press.

Beck, U. (2009) World at Risk. Cambridge, UK/Malden, MA: Polity Press.

Beck, U. (2010) A God of One's Own: Religion's Capacity for Peace and Potential for Violence. Cambridge, UK/Malden, MA: Polity Press.

Beck, U. (2011) 'Cosmopolitanism as Imagined Communities of Global Risk', Edward A. Tiryakian, guest editor, 'Imagined Communities' in the $21^{\text {st }}$ Century. Special issue of American Behavioral Scientist 55(10): 1346-1361.

Beck, U. (2012) Twenty Observations on a World in Turmoil. Cambridge, UK/Malden, MA: Polity Press.

Beck, U. and E. Beck-Gernsheim (2002) Individualization: Institutionalized Individualism and its Social and Political Consequences.
London/Thousand Oaks/New Delhi: Sage Publications.

Beck, U. and E. Beck-Gernsheim (2009) 'Global Generations and the Trap of Methodological Nationalism: For a Cosmopolitan Turn in the Sociology of Youth and Generation', European Sociological Review 25(1): 25-36.

Beck, U. and E. Grande (2007) Cosmopolitan Europe. Cambridge, UK/Malden, MA: Polity Press.

Beck, U. and E. Grande (eds) (2010a) 'Special Issue on Varieties of Second Modernity: ExtraEuropean and European Experiences and Perspectives', British Journal of Sociology 61(3).

Beck, U. and E. Grande (2010b) 'Varieties of Second Modernity: The Cosmopolitan Turn in Social and Political Theory and Research', British Journal of Sociology 61(3): 409-443.

Beck, U. and C. Kropp (2007) 'Environmental Risks and Public Perceptions', pp. 601-611 in J. Pretty et al. The Sage Handbook of Environment and Society. Los Angeles/London/New Delhi/ Singapore: Sage Publications.

Beck, U. and N. Sznaider (eds) (2006a) 'Special Issue on Cosmopolitan Sociology', British Journal of Sociology 57(1).

Beck, U. and N. Sznaider (2006b) 'Unpacking Cosmopolitanism for the Social Sciences', British Journal of Sociology 57(1): 1-23.

Beck, U. and N. Sznaider (2006c) 'A Literature on Cosmopolitanism: An Overview', British Journal of Sociology 57(1): 153-164.

Beck, U. and N. Sznaider (2010) 'New Cosmopolitanism in the Social Sciences', pp. 635-652 in B. S. Turner (ed.) The Routledge International Handbook of Globalization Studies. Abingdon, Oxon/ New York: Routledge.

Benhabib, S. (2007) 'Twilight of Sovereignty or the Emergence of Cosmopolitan Norms? Rethinking Citizenship in Volatile Times', pp. 247-271 in T. Faist and P. Kivisto (eds) Dual Gitizenship in Global Perspective: From Unitary to Multiple Citizenship. Houndmills, UK/New York: Palgrave Macmillan.

Billig,M.(1995) BanalNationalism.London:Sage.

Boltanski, L. (1999) Distant Suffering: Politics, Morality and the Media. Cambridge: Cambridge University Press. 
Boon, V. and R. Fine (eds) (2007) 'Special Issue on Cosmopolitanism: Between Past and Future', European Journal of Social Theory 10(1).

Brubaker, R. and F. Cooper (2000) 'Beyond "Identity", Theory and Society 29(1): 1-47.

Breckenridge, C. et al. (eds) (2002) Cosmopolitanism. Durham: Duke NC University Press.

Brown, G. W. (2008) 'Moving from Cosmopolitan Legal Theory to Legal Practice: Models of Cosmopolitan Law', Legal Studies 28(3): 430-451.

Calcutt, L., I. Woodward and Z. Skrbis (2009) 'Conceptualising Otherness: An Exploration of the Cosmopolitan Schema', Journal of Sociology 45(2): 169-186.

Calhoun, C. (2003) 'Belonging' in the Cosmopolitan Imaginary', Ethnicities, 3(4): 531-568.

Calhoun, C. (2006) Nations Matter: Citizenship, Solidarity and the Cosmopolitan Dream. London: Routledge.

Calhoun, C. (2007) Cosmopolitanism and Belonging: From European Integration to Global Hopes and Fears. London: Routledge.

Chang K.-S. and Song M.-Y. (2010) 'The Stranded Individualizer under Compressed Modernity: South Korean Women in Individualization without Individualism', British Journal of Sociology 61(3): 539-564.

Cheah, P. (2006) Inhuman Conditions: On Cosmopolitanism and Human Rights. Cambridge, MA/ London: Harvard University Press.

Cheah, P. and B. Robbins (eds) (1998) Cosmopolitics: Thinking and Feeling Beyond the Nation. Minneapolis: University of Minnesota Press.

Chouliaraki, L. (2006) The Spectatorship of Suffering. London: Sage.

Clausen, L. (2003) Global Nerws Production. Copenhagen: Copenhagen Business School Press.

Constellations - An International Journal of Critical and Democratic Theory (2003): 10(4) 'Cosmopolitanism as Critique'.

Cottle, S. (2009) Global Crisis Reporting: Journalism in the Global Age. Maidenhead: Open University Press.

Croucher, S. L. (2003) 'Perpetual Imagining: Nationhood in a Global Era', International Studies Review 5(1): 1-24.
Daedalus - Journal of the American Academy of Arts \& Sciences (2008): 137(3) 'On Cosmopolitanism'.

Dayan, D. and E. Katz (1992) Media Events: The Live Broadcasting of History. Cambridge, MA: Harvard University Press.

Delanty, G. (2006) 'Nationalism and Cosmopolitanism: The Paradox of Modernity', pp. 357368 in G. Delanty and K. Kumar (eds) The Sage Handbook of Nations and Nationalism. London: Sage Publications.

Delanty, G. (2009) The Cosmopolitan Imagination: The Renewal of Critical Social Theory. Cambridge, UK/New York: Cambridge University Press.

Dewey, J. (1927) The Public and its Problems. New York: Holt.

Dobson, A. (2006) 'Thick Cosmopolitanism', Political Studies 54(1): 165-184.

Elias, N. (1978) What is Sociology? New York: Columbia University Press.

Elias, N. (1992) Time: An Essay. Oxford, UK/ Cambridge, MA: Backwell Publishers.

Fairclough, N. (2006) Language and Globalization. London/New York: Routledge.

Featherstone, M. et al. (eds) (2002) 'Special issue on Cosmopolis', Theory, Culture E' Society 19(1-2).

Fine, R. (2007) Cosmopolitanism. London/New York: Routledge.

Fine, R. and D. Chernilo (2004) 'Between Past and Future: The Equivocations of the New Cosmopolitanism', Studies in Law, Politics, and Society 31: $25-44$

Frosh, P. (2011) 'Phatic Morality: Television and Proper Distance' International Journal of Cultural Studies 14(4): 383-400.

Gross, D. (1985) 'Temporality and the Modern State', Theory and Society 14(1): 53-82.

Grusin, R. (2010) Premediation: Affect and Mediality after 9/11. Houndmills/New York: Palgrave Macmillan.

Hall, S. (1997) 'The Spectacle of the 'Other', pp. 223-290 in S. Hall (ed.) Representation: Cultural Representations and Signifying Practices. London/ Thousand Oaks/New Delhi: Sage Publications 
Held, D. (2002) 'Law of States, Law of Peoples: Three Models of Sovereignty', Legal Theory 8(1): 1-44.

Held, D. (2010) Cosmopolitanism: Ideals, Realities E Deficits. Cambridge, UK/Malden, MA: Polity Press.

Hier, S. P. (2008) 'Transformative Democracy in the Age of Second Modernity: Cosmopolitanization, Communicative Agency and the Reflexive Subject', New Media E Society 10(1): 27-44.

Hobsbawm E. J. (1990) Nations and Nationalism since 1780: Programme, Myth, Reality. Cambridge, UK/New York, NY: Cambridge University Press.

Höijer, B. (2004) 'The Discourse of Global Compassion: The Audience and Media Reporting of Human Suffering', Media, Culture and Society 26(4): 513-531.

Kaldor, M. (2007) New E Old Wars: Organized Violence in a Global Era. Stanford: Stanford University Press.

Kendall, G., I. Woodward and Z. Skrbis (2009) The Sociology of Cosmopolitanism: Globalization, Identity, Culture and Government. London: Palgrave Macmillan.

Khagram, S. and P. Levitt (eds) (2008) The Transnational Studies Reader: Intersections and Innovations. London/New York: Routledge.

Koselleck, R. (1985) Futures Past: On the Semantics of Historical Time. New York: Columbia Press.

Kurasawa, F. (2004) 'A Cosmopolitanism from Below: Alternative Globalization and the Creation of a Solidarity without Bounds', Archives of European Sociology 45(2): 233-255.

Kyriakidou, M. (2009) 'Imagining Ourselves Beyond the Nation? Exploring Cosmopolitanism in Relation to Media Coverage of Distant Suffering', Studies in Ethnicity and Nationalism 9(3): 481-496.

Lamont, M. and S. Aksartova (2002) 'Ordinary Cosmopolitanisms: Strategies for Bridging Racial Boundaries AmongWorking-Class Men', Theory, Culture E Society 19(4): 1-25.

Levy, D., M. Heinlein and L. Breuer (2011) 'Reflexive Paricularism and Cosmopolitanization: The Reconfiguration of the National', Global Networks 11(2): 139-159.
Levy, D. and N. Sznaider (2006a) The Holocaust and Memory in the Global Age. Philadelphia, PA: Temple University Press.

Levy, D. and N. Sznaider (2006b) 'Sovereignty Transformed: A Sociology of Human Rights', British Journal of Sociology 57(4): 657-676.

Levy, D. and N. Sznaider (2010) Human Rights and Memory. University Park, PA: The Pennsylvania University Press.

Mau, S., J. Mewes and A. Zimmermann (2008) 'Cosmopolitan Attitudes through Transnational Social Practices', Global Networks 8(1): 1-24.

Miller, T. (ed.) (2008) Given World and Time: Temporalities in Context. Budapest: CEU Press.

Misztal, B. (2001) 'Legal Attempts to Construct Collective Memory: The Necessity and Difficulties of Aiming for Both truth and Solodarity', Polish Sociological Review 133: 61-75.

Moeller, S. D. (1999) Compassion Fatigue: How the Media Sell Disease, Famine, War and Death. New York: Routledge.

Nederveen Pieterse, J. (2006) 'Emancipatory Cosmopolitanism: Towards an Agenda', Development and Change 37(6): 1247-1257.

Nowicka, M. and M. Rovisco (eds) (2009) Cosmopolitanism in Practice. Farnham/Burlington: Ashgate.

Nussbaum, M. (1996) 'Patriotism and Cosmopolitanism', pp. 3-20 in J. Cohen (ed.) For Love of Country? Boston: Beacon Press.

Pichler, F. (2008) 'How Real is Cosmopolitanism in Europe?', Sociology 42(6): 1107-1126.

Rapport, N. (2007) 'An Outline for Cosmopolitan Study: Reclaiming the Human through Introspection', Current Anthropology 48(2): 257-283.

Ribes, A. J. (2010) 'Theorising Global Media Events: Cognition, Emotions and Performances', New Global Studies 4(3): Article 3.

Robbins, B. (1998) 'Introduction Part I: Actually Existing Cosmopolitanism', pp. 1-19 in P. Cheah and B. Robbins (eds) Cosmopolitics: Thinking and Feeling Beyond the Nation. Minneapolis: University of Minesota Press.

Robertson, A. (2010) Mediated Cosmopolitanism: The World of Television Nerws. Cambridge, UK/ Malden, MA: Polity Press. 
Roudometof, V. and W. Haller (2007) 'Social Indicators of Cosmopolitanism and Localism in Eastern and Western Europe: An Exploratory Analysis', pp. 181-201 in C. Rumford (ed.) Cosmopolitanism and Europe. Liverpool: Liverpool University Press.

Rumford, C. (ed.) (2007) Cosmopolitanism and Europe. Liverpool: Liverpool University Press.

Saito, H. (2011) 'An Actor-Network Theory of Cosmopolitanism', Sociological Theory 29(2): 124-149.

Savelsberg, J.J. and R.D. King (2007) 'Law and Colective Memory', Annual Review of Law and Social Science 3: 189-211.

Silverstone, R. (2007) Media and Morality: On the Rise of the Mediapolis. Cambridge, UK/Malden, MA: Polity Press.

Simmel, G. (2004) The Philosophy of Money. London/New York: Routledge.

Skrbis, Z., G. Kendall and I. Woodward (2004) 'Locating Cosmopolitanism: Between Humanist Ideal and Grounded Social Category', Theory, Culture E Society 21(6): 115-136.

Soysal, Y. (1994) Limits of Citizenship: Migrants and Postnational Membership in Europe. Chicago: Chicago University Press.

Suzuki, M. et al (2010) 'Individualizing Japan: Searching for its Origins in First Modernity', British Journal of Sociology 61(3): 513-538.

Tester, K. (2001) Compassion, Morality and the Media. Buckingham/Philadelphia: Open University Press.

The Hedgehog Review - Critical Reflections on Contemporary Culture (2009): 11(3) 'The Cosmopolitan Predicament'.

Urry, J. (2000) 'The Global Media and Cosmopolitanism', Sociology, Lancaster University http:// www.lancs.ac.uk/fass/sociology/papers/urry-globalmedia.pdf.

Vertovec, S. and R. Cohen (eds) (2002) Conceiving Cosmopolitanism: Theory, Context and Practice. Oxford: Oxford University Press.

Walker, R.B.J.(1990) 'Sovereignty, Identity, Community: Reflections on the Horizons of Contemporary Political Practice', pp. 159-185 in R.B.J. Walker and S. H. Mendlovitz (eds) Contending
Sovereignties: Redefining Political Community. Boulder: Lynne Rienner.

Werbner, P. (ed.) (2008) Anthropology and the New Cosmopolitanism: Rooted, Feminist and Vernacular Perspectives. Oxford, UK/New York: Berg.

Werner, M. and B. Zimmermann (2006) 'Beyond Comparison: Histoire Croisée and the Challenge of Reflexivitity', History and Theory 45(1): 30-50

Wimmer, A. and Glick Schiller, N. (2002) 'Methodological Nationalism and Beyond: Nation-State Building, Migration and the Social Sciences', Global Networks 2(4): 301-334.

Wilkinson, I. (2012) 'Humanitarism and Cosmpolitanism', in G. Delanty (ed.) The Routledge Handbook of Cosmopolitanism Studies. London/ New York: Routledge (forthcoming).

Yan, Y. (2010) 'The Chinese Path to Individalization', British Journal of Sociology 61(3): 489-512. 


\section{Working Papers : dernières parutions}

Hervé Le Bras, Jean-Luc Racine \& Michel Wieviorka, National Debates on Race Statistics: towards an International Comparison, FMSHWP-2012-01, février 2012.

Manuel Castells, Ni dieu ni maître : les réseaux, FMSH-WP-2012-02, février 2012.

François Jullien, L'écart et l'entre. Ou comment penser l'altérité, FMSH-WP-2012-03, février 2012.

Itamar Rabinovich, The Web of Relationship, FMSH-WP-2012-04, février 2012.

Bruno Maggi, Interpréter l'agir : un défi théorique, FMSH-WP-2012-05, février 2012.

Pierre Salama, Chine - Brésil : industrialisation et "désindustrialisation précoce ", FMSHWP-2012-06, mars 2012.

Guilhem Fabre \& Stéphane Grumbach, The World upside down, China's RED and innovation strategy, FMSH-WP-2012-07, avril 2012.

Joy Y. Zhang, The De-nationalization and Renationalization of the Life Sciences in China: $A$ Cosmopolitan Practicality?, FMSH-WP-2012-08, avril 2012.

John P. Sullivan, From Drug Wars to Criminal Insurgency: Mexican Cartels, Criminal Enclaves and Criminal Insurgency in Mexico and Central America. Implications for Global Security, FMSHWP-2012-09, avril 2012.

Marc Fleurbaey, Economics is not what you think: $A$ defense of the economic approach to taxation, FMSH-WP-2012-10, may 2012.

Marc Fleurbaey, The Facets of Exploitation, FMSH-WP-2012-11, may 2012.

Jacques Sapir, Pour l'Euro, l'heure du bilan a sonné : Quinze leçons et six conclusions, FMSHWP-2012-12, juin 2012.

Rodolphe De Koninck \& Jean-François Rousseau, Pourquoi et jusquioù la fuite en avant des agricultures sud-est asiatiques?, FMSH-WP-2012-13, juin 2012.

Jacques Sapir, Inflation monétaire ou inflation structurelle ? Un modèle hétérodoxe bi-sectoriel, FMSH-WP-2012-14, juin 2012.
Franson Manjali, The 'Social' and the 'Cognitive' in Language. A Reading of Saussure, and Beyond, FMSH-WP-2012-15, july 2012.

Michel Wieviorka, Du concept de sujet à celui de subjectivation/dé-subjectivation, FMSHWP-2012-16, juillet 2012.

Nancy Fraser, Feminism, Capitalism, and the Cunning of History: An Introduction, FMSHWP-2012-17 august 2012.

Nancy Fraser, Can society be commodities all the way down? Polanyian reflections on capitalist crisis, FMSH-WP-2012-18, august 2012.

Marc Fleurbaey \& Stéphane Zuber, Climate policies deserve a negative discount rate, FMSHWP-2012-19, september 2012.

Roger Waldinger, La politique au-delà des frontières : la sociologie politique de l'émigration, FMSH-WP-2012-20, septembre 2012.

Antonio De Lauri, Inaccessible Normative Pluralism and Human Rights in Afghanistan, FMSHWP-2012-21, september 2012.

Dominique Méda, Redéfinir le progrès à la lumière de la crise écologique, FMSH-WP-2012-22, octobre 2012.

Ibrahima Thioub, Stigmates et mémoires de l'esclavage en Afrique de l'Ouest : le sang et la couleur de peau comme lignes de fracture, FMSHWP-2012-23, octobre 2012.

Danièle Joly, Race, ethnicity and religion: social actors and policies, FMSH-WP-2012-24, novembre 2012.

Dominique Méda, Redefining Progress in Light of the Ecological Crisis, FMSH-WP-2012-25, décembre 2012.

Ulrich Beck \& Daniel Levy, Cosmopolitanized Nations: Reimagining Collectivity in World Risk Society, FMSH-WP-2013-27, february 2012. 